\title{
GROWING SUNFLOWER PLANTS FROM SEED TO SEED IN SMALL POTS IN GREENHOUSE
}

\author{
Hu, J.. ${ }^{*}$, Yue, B. ${ }^{2}$, Yuan, W. ${ }^{3}$ and Vick, B.A. ${ }^{1}$ \\ ${ }^{1}$ USDA-Agricultural Research Service, Northern Crop Science Laboratory, \\ 1307 North $18^{\text {th }}$ Street, Fargo, ND 58105, USA \\ ${ }^{2}$ Department of Plant Sciences, North Dakota State University, \\ Fargo, ND 58105, USA \\ ${ }^{3}$ Langfang Academy of Agriculture and Forestry Sciences, \\ Langfang City, 065000, Hebei Province, P.R. China
}

Received: January 21, 2008 Accepted: May 18, 2008

\section{SUMMARY}

This paper reports the results of two experiments in which sunflower plants were grown from seed to seed in small pots to utilize greenhouse space efficiently. We used small plastic pots $(9.0 \times 8.6 \times 9.0 \mathrm{~cm})$ filled with approximately half a liter of potting soil in a temperature-controlled greenhouse with a light : dark cycle of $14: 10 \mathrm{~h}$. In the first experiment, $100 \mathrm{~F}_{2: 5}$ plants were grown on a two-square-meter bench in the greenhouse during the winter of 2007. Ninety-eight of the 100 plants survived to maturity and produced an average of 62 viable seeds with a range of 36 to 102 seeds per plant. In comparison to the plants grown in six-liter pots, we observed that all the plants grown in the small pots had a significant decrease in plant size such as height, head diameter, and number of seeds per plant. The plants grown in the small pots flowered on average 9 days later than those in the large pots. No significant difference was observed for germination rate between the seeds harvested from small and large pots. In the second experiment, two oilseed and two confectionery sunflower inbred lines were grown during the summer of 2007 to confirm the observations from the first experiment. The results were essentially the same as those observed in the first experiment. For number of seed produced per plant, an average of 13.0 to 42.2 seeds were obtained per head for each of the four lines grown in small pots, with no significant difference observed between oil and confectionery sunflower. Thus, our results suggest that it is possible to produce viable seeds from plants grown in small pots. This method should be useful for efficient line advancement in the greenhouse for breeding and genetic studies.

Key words: line advancing, small pots, greenhouse, sunflower

* Corresponding author: e-mail: jinguo.hu@ars.usda.gov

Remarks: Mention of trade names or commercial products in this article is solely for the purpose of providing specific information and does not imply recommendation or endorsement by the U.S. Department of Agriculture. 


\section{INTRODUCTION}

Sunflower is one of the most popular crops in the world and is grown for oil, food, and ornamental purposes. Although traditional sunflower cultivars are openpollinated varieties, almost all modern cultivars are $\mathrm{F}_{1}$ hybrids produced by using cytoplasmic male sterility (Fick and Miller, 1997). New hybrids with improved quality and high yield are continuously developed by the seed industry. The cultivated sunflower plants are generally between one and two meters tall, and a single plant requires a greenhouse space of approximately one-half square meter to grow normally. Only a limited number of plants can be accommodated in greenhouses because of limited space. For example, fewer than 100 sunflower plants can be planted in two-gallon pots in a greenhouse of 50 square meters. In practice, growing sunflower plants from seed to seed in a breeding program is usually accomplished in field plots during the growing season or in a winter nursery during the off-season. Thus, researchers can typically grow sunflower for only two generations a year. This paper reports the results of growing sunflower plants from seed to seed in small plastic pots $(9.0 \times 8.6 \times 9.0 \mathrm{~cm})$ in the greenhouse. Our results indicated that it is possible to produce viable seeds from plants grown in small pots and to increase greenhouse space usage efficiency by growing sunflower plants in small pots. This method will be useful for breeders to advance sunflower breeding materials and for geneticists to develop mapping populations of recombinant inbred lines easily and without the need for winter nurseries.

\section{MATERIALS AND METHODS}

\section{Plant materials}

In the first experiment, a total of 100 single-seed decent (SSD) $\mathrm{F}_{2: 5}$ lines derived from a cross between RHA 271 and HA 234 were grown in small pots during the winter of 2007. We planned to develop a recombinant inbred line (RIL) population from this cross since a linkage map of 230 RFLP markers was constructed from an $\mathrm{F}_{2}$ population of the same two parental lines (Jan et al., 1997).

In the summer of 2007, two oilseed sunflower lines, HA 89 and HA 441, and two confectionery sunflower lines, HA 285 and HA 319, were used in the second experiment.

\section{Greenhouse supplies}

Small plastic vacuum-formed square pots $(9.0,8.6$ and $9.0 \mathrm{~cm}$ for depth, topinside and top-outside dimensions, respectively) (T.O. Plastics Inc., Clearwater, $\mathrm{MN}$ ), large $20 \mathrm{~cm}$ (diameter) round plastic pots (National Polymers Inc., Lakeville, MN), and Sunshine potting soil (Sun Gro Horticulture Inc., Bellevue, WA) were used for growing sunflower plants.

\section{Greenhouse conditions and management}

A day time temperature of $25^{\circ} \mathrm{C}$ and night time of $22^{\circ} \mathrm{C}$ and a lighting cycle of 14/10 h (light/dark) were maintained during the growing period. On February 6, 
2007, two to three seeds of each $\mathrm{F}_{2: 5}$ line were planted in each small pot filled with approximately 0.51 of potting soil. The pots were placed on a single bench in a greenhouse equipped with high-intensity halogen lights in Fargo, ND. Two weeks after germination the pots were thinned to one seedling. The pots were watered on a daily basis until mature. At the same time, seeds from ten randomly chosen lines were planted in the large six-liter plastic pots to observe morphological differences. Water-soluble fertilizer (Jack's, J.R. Peters Inc., Allentown, PA) was applied two times during the seedling stage. The fertilizer was dissolved in water and applied directly to the pots. For the large pots, fertilizer was applied once a week until flowering. Chemicals were applied three times to control pests.

In the second experiment, the four lines were planted on July 19, 2007 in small and large pots with three replicates of each line. The greenhouse management was the same as in the first experiment.

\section{Observations on morphological traits}

A number of growth and morphological traits were determined for each of the ten plants in both small and large pots in the first experiment and for all the plants in the second experiment. Flowering dates for the plants were recorded, and days to flowering were calculated. At maturity, plant height and head diameter were measured, and after harvest, the number of filled seeds per head was counted. A germination test was conducted only for the seeds harvested from the first experiment. Forty seeds per line were placed in a Petri dish with a filter paper, sufficient water was added, and the Petri dishes placed in the dark at $25^{\circ} \mathrm{C}$ for one week.

\section{RESULTS}

Table 1 and Figure 1 show the plants and their agronomic performance for the five traits observed in the first experiment. In general, the days to flowering of the plants in the small pots was delayed 9 days on average as compared with the plants in large pots. The plant height, head diameter and number of filled seeds per head were significantly reduced. No significant difference was observed in the germination test between the seeds harvested from small and large pots (Table 1).

Table 1: Differences observed between sunflower plants grown in large and small pots in experiment one

\begin{tabular}{lcccc}
\hline \multirow{2}{*}{ Trait } & \multicolumn{2}{c}{ Large pots (6 I) } & \multicolumn{2}{c}{ Small pots (0.5 I) } \\
\cline { 2 - 5 } & Mean & Range & Mean & Range \\
\hline Days to flowering & 60 & $54-65$ & $69^{*}$ & $57-75$ \\
Plant height $(\mathrm{cm})$ & $121.4^{\star *}$ & $108.0-142.0$ & 87.4 & $71.0-101.0$ \\
Head diameter (cm) & $8.5^{\star *}$ & $7.0-10.0$ & 4.9 & $3.0-6.5$ \\
Number of filled seeds per head & $115.1^{\star *}$ & $60-192$ & 62.0 & $36-102$ \\
Germination rate (\%) & 93.6 & $82.5-100$ & 95.1 & $91.3-100$ \\
\hline
\end{tabular}

${ }^{\star},{ }^{\star \star}$ significant at the 0.05 and 0.01 probability levels between the means from large and small pots, respectively. 
Although the plant height and head size decreased when seeds were planted in small pots, more than 36 seeds were harvested for each plant, which is sufficient for advancing to the next generation. Thus, within an area of about two square meters, 100 plants were grown to maturity and 98 of them produced viable seeds in this study, suggesting it is possible to advance seeds on a large scale in limited greenhouse space.

Table 2: Differences observed between sunflower plants (two confection and two oil sunflower lines) grown in large and small pots in experiment two. All numbers are the averages of three replications for each inbred line

\begin{tabular}{|c|c|c|c|c|c|}
\hline \multicolumn{2}{|c|}{ Variety } & $\begin{array}{c}\text { Days to } \\
\text { flowering }\end{array}$ & $\begin{array}{l}\text { Plant height } \\
\text { (cm) }\end{array}$ & $\begin{array}{l}\text { Head diameter } \\
(\mathrm{cm})\end{array}$ & $\begin{array}{l}\text { Number of filled } \\
\text { seeds per head }\end{array}$ \\
\hline \multirow[t]{4}{*}{ Large pot } & HA 285 & 57 & $109.7^{*}$ & $15.0^{\star \star}$ & $153.6^{\star \star}$ \\
\hline & HA319 & 63 & $116.8^{\star *}$ & $11.5^{\star *}$ & $90.3^{\star \star}$ \\
\hline & HA 89 & 56 & 96.0 & $10.5^{\star}$ & $317.3^{* *}$ \\
\hline & HA 441 & 58 & $110.9^{*}$ & $11.7^{\star \star}$ & $192.0^{\star *}$ \\
\hline \multirow[t]{4}{*}{ Small pot } & HA 285 & 59 & 103.4 & 6.4 & 26.0 \\
\hline & HA 319 & $68^{*}$ & 99.3 & 5.7 & 15.4 \\
\hline & HA 89 & $61^{*}$ & 103.4 & 6.2 & 42.2 \\
\hline & HA 441 & 61 & 104.9 & 6.6 & 13.0 \\
\hline
\end{tabular}

*,** significant at the 0.05 and 0.01 probability levels between the means from large and small pots, respectively.

The agronomic performances for the traits in the second experiment are presented in Table 2. In general, the data confirmed the observations from the first experiment: flowering dates were delayed 3.8 days on average, while plant height, head diameter and number of filled seeds per head decreased significantly. No significant differences were observed between confectionery and oilseed sunflower.

\section{DISCUSSION}

The results of the two experiments showed that growing sunflower plants from seed to seed can be achieved in small pots in the greenhouse. This method could be useful in sunflower breeding programs. The goal of sunflower breeding is to develop inbred lines to be used as parent lines to produce superior $F_{1}$ hybrids. Various methods have been used in sunflower breeding (Miller, 1987). Currently, few breeders conduct field evaluation of the segregating progeny at early generations $\left(\mathrm{F}_{2}\right.$ to $\mathrm{F}_{5}$ ); thus, it would be desirable if the segregating materials could be advanced as fast as possible to the $\mathrm{F}_{6}$ generation. Theoretically, the homozygosity will be greater than $99 \%$ if the population is derived from a cross between two inbred lines, and therefore the heritability of a selected trait will be higher (Allard, 1999).

Generally, breeding of genetic populations can be advanced for 3 generations in one year, two generations in the greenhouse (from October to January and from February to April) and one generation in the field (May to September). One obstacle 

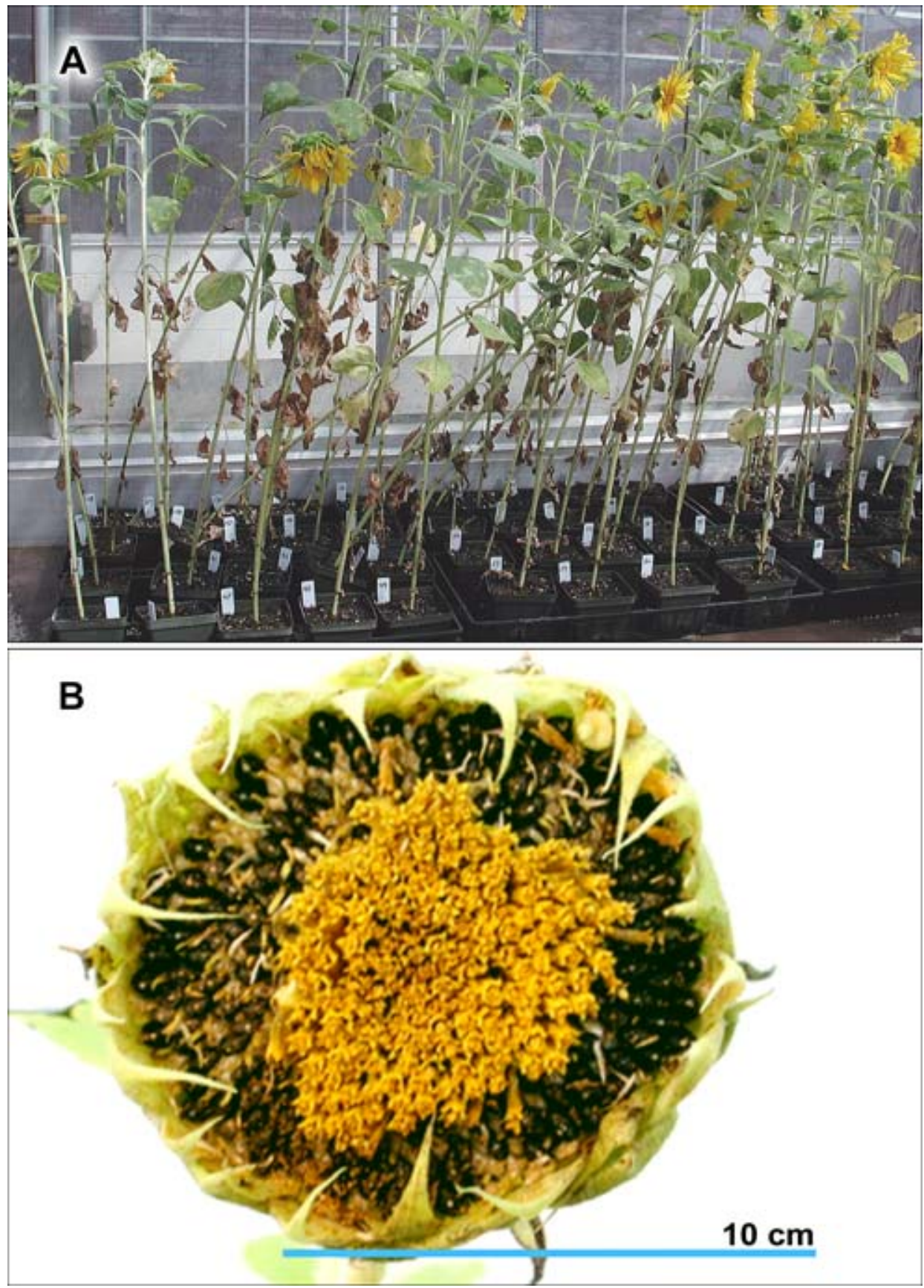

Figure 1: Sunflower plants grown in small pots in the first experiment. A) Plants at the flowering stage; B) A mature sunflower head 
to rapid cycling of generations is that freshly harvested, mature seeds of most sunflower lines do not germinate due to dormancy. However, the embryos of immature seeds 10 days after pollination can be germinated on agar medium or even on a wet filter paper under sterile conditions. This has been a common practice to shorten the time of generation cycle in a breeding program. Coupled with embryo culture, the use of small pots in the greenhouse could make it possible in one year to produce 4 generations of a large number of segregating progenies for selection and breeding purposes.

RILs are powerful tools for genetic mapping (Lister and Dean, 1993). A RIL population is formed by crossing two inbred lines followed by repeated selfing for seven or more generations. The advantages of RILs in genetic mapping include a better measurement on genotype by environment interactions because one genotype can be tested in multiple environments, and a greater mapping resolution due to a denser recombinant point than those in the $\mathrm{F}_{2}$ population. However, as the development of RIL populations is time consuming, most genetic mapping studies have been conducted with $\mathrm{F}_{2}$ populations (Bert et al., 2002; Mestries et al., 1998) and fewer RIL populations have been used (Tang et al., 2002). This method could also be useful to rapidly develop recombinant inbred line (RIL) populations of sunflower for genetic studies.

When growing sunflower plants in small pots to produce seeds, several cultural techniques need to be kept in mind. These include:

1. supply sufficient light intensity to decrease plant height, especially at the seedling stage;

2. apply less fertilizer to inhibit growth in the vegetative stage;

3. control pests on time; and

4. water sufficiently, especially at the flowering stage.

\section{ACKNOWLEDGMENT}

The authors appreciate the technical assistance of Angelia Hogness, USDA-ARS, Fargo, ND.

\section{REFERENCES}

Allard, R.W., 1999. Principles of Plant Breeding. Second Edition, John Wiley \& Sons, Inc. New York, London.

Bert, P.F., Jouan, I., Tourvieille de Labrouhe, D., Serre, F., Nicolas, P., Vear, F., 2002. Comparative genetic analysis of quantitative traits in sunflower (Helianthus annuus L.) 1. QTL involved in resistance to Sclerotinia sclerotiorum and Diaporthe helianthi. Theor. Appl. Genet. 105: 985-993.

Fick, G.N., Miller, J.F., 1997. Sunflower breeding. In: Schneiter AA (ed) Sunflower Technology and Production. ASA, CSSA, SSSA publishers, Madison, Wisconsin, USA, pp. 395-439.

Jan, C.C., Vick, B.A., Miller, J.F., Kahler, A.L., Butler, E.T., 1998. Construction of an RFLP linkage map for cultivated sunflower. Theor. Appl. Genet. 96: 15-22. 
Lister, C., Dean, C., 1993. Recombinant inbred lines for mapping RFLP and phenotypic markers in Arabidopsis thaliana. Plant J. 4: 745-750.

Mestries, E., Gentzbittel, L., Tourvieille de Labrouhe, D., Nicolas, P., Vear, F., 1998. Analyses of quantitative trait loci associated with resistance to Sclerotinia sclerotiorum in sunflowers (Helianthus annuus L.) using molecular markers. Mol. Breed. 4: 215-226.

Tang, S., Yu, J.K., Slabaugh, M.B., Shintani, D.K., Knapp, S.J., 2002. Simple sequence repeat map of the sunflower genome. Theor. Appl. Genet. 105: 1124-1136.

\title{
CULTIVO DE PLANTAS DE GIRASOL DE SEMILLA A SEMILLA EN MACETAS PEQUEÑAS EN INVERNADERO
}

\author{
RESUMEN
}

Este trabajo informa los resultados de dos experimentos en los que se cultivaron plantas de girasol de semilla a semilla en macetas pequeñas para utilizar eficientemente el espacio de invernadero. Se utilizaron macetas plásticas pequeñas $(9,0 \times 8,6 \times 9,0 \mathrm{~cm})$ llenadas con aproximadamente medio litro de suelo de maceta en un invernadero de temperatura controlada con un ciclo luz:oscuridad de 14:10 h. En el primer experimento se cultivaron 100 plantas $\mathrm{F}_{2: 5}$ en una cama de siembra de dos metros cuadrados en un invernadero durante el invierno 2007. Noventa y ocho de las cien plantas sobrevivieron hasta madurez y produjeron un promedio de 62 semillas viables en un rango de 36 a 102 semillas por planta. En comparación con las plantas cultivadas en las macetas de 6 litros, observamos que todas las plantas cultivadas en las macetas pequeñas tuvieron una reducción significativa en el tamaño de planta incluyendo la altura, el diámetro de capítulo y el número de semillas por planta. Las plantas cultivadas en macetas pequeñas en promedio florecieron nueve días más tarde que aquellas cultivadas en macetas grandes. No se observaron diferencias significativas para tasa de germinación entre las semillas cosechadas de macetas grandes y pequeñas. En el segundo experimento se cultivaron dos líneas de girasol confitero y dos líneas de girasol oleaginoso durante el verano 2007 con el objetivo de confirmar las observaciones del primer experimento. Los resultados fueron esencialmente los mismos observados en el primer experimento. Para número de semillas producidas por planta, se obtuvo un promedio de 13,0 a 42,2 semillas por capítulo por cada una de las cuatro líneas cultivadas en macetas pequeñas sin diferencias significativas observables entre girasol oleaginoso y confitero. En consecuencia, nuestros resultados sugieren que es posible producir semillas viables a partir de plantas cultivadas en macetas pequeñas. Este método debería ser útil para el avance eficiente de líneas en invernadero para estudios genéticos y de mejoramiento.

\section{LE DÉVELOPPEMENT DE PLANTES À PARTIR D'UNE TECHNIQUE GRAINE À GRAINE EN PETITS POTS EN SERRE.}

\author{
RÉSUMÉ
}

Ce papier rapporte les résultats de deux expérimentations de culture de plantes de tournesol de "semence à semence" en petits pots pour utiliser l'espace de la serre de manière efficace. Nous avons utilisé des petits pots en plastique $(9.0 \times 8.6 \times 9.0 \mathrm{~cm})$ remplis d'approximativement un demi-litre de terre de pot dans une serre à température contrôlée avec lumière: cycle 
d'obscurité de 14:10 h. Lors de la première expérience, $100 \mathrm{~F}_{2: 5}$ plants ont poussé sur un banc d'essai de deux mètres carrés de la serre pendant l'hiver 2007. 98 des 100 plantes ont survécu jusqu'à maturité et ont produit une moyenne de 62 semences viables avec 36 à 102 graines par plante. En comparant avec les plants cultivés dans des pots de 6 litres, nous avons observé que toutes les plantes qui ont poussées dans des petits pots étaient plus réduites de manière significative telle que la hauteur, le diamètre du capitule et le nombre de graines par plante. Les plantes ayant poussées dans des petits pots ont fleuries en moyenne neuf jours après celle des gros pots. Aucune différence significative n'a été observée pour le taux de germination entre les semences récoltées dans les petits ou gros pots. Dans la seconde étude, deux lignées classiques et deux lignées de tournesol de bouche ont poussé lors de l'été 2007 afin de confirmer les observations de la $1^{\text {ère }}$ étude. Pour un nombre de graine produite par plant, une moyenne de 13.0 à 42.2 graines a été obtenue par capitule pour chacune des 4 lignées cultivées en petits pots, avec aucune différence significative observée entre huile et tournesol de bouche. Ainsi, nos résultats suggèrent qu'il est possible de produire des semences viables à partir de plantes cultivés dans des petits pots. Cette méthode pourrait s'avérer utile pour un avancement efficace de la lignée en serre pour la reproduction et les études génétiques. 